\title{
Pemanfaatan media youtube untuk mendukung e-learning pendidikan kewarganegaraan di perguruan tinggi
}

\author{
Ricky Santoso Muharam, Danang Prasetyo
}

Sekolah Tinggi Pariwisata Ambarrukmo, Yogyakarta, Indonesia

\section{INFORMASI ARTIKEL}

Sejarah Artikel:

Diterima: 10/01/2021

Disetujui: 02/03/2021

Kata kunci:

Media Pembelajaran;

Youtube;

Pendidikan

Kewarganegaraan;

Perguruan Tiinggi

Keywords:

Learning media;

Youtube;

Civic Education;

Higher Education

\begin{abstract}
ABSTRAK
Perubahan proses perkuliahan pendidikan kewarganegaraan dari tatap muka langsung menjadi pembelajaran jarak jauh melalui jaringan menuntut perlunya inovasi dan kreativitas pendidik dalam mengembangkan media pembelajaran. Youtube adalah platform yang dapat dikembangkan dosen dalam mendukung pembelajaran dalam jaringan. Tujuan penelitian ini adalah untuk mengetahui respons mahasiswa terhadap youtube yang dikembangkan dosen sebagai media pembelajaran pendidikan kewarganegaraan dalam jaringan. Penelitian dilakukan secara deskriptif analitis kepada mahasiswa peserta kuliah pendidikan kewarganegaraan di STP Ambarrukmo Yogyakarta. Hasil penelitian menunjukkan bahwa pemanfaatan media youtube yang dikembangkan dosen dapat membantu mahasiswa dalam memahami materi-materi perkuliahan pendidikan kewarganegaraan. Namun demikian, dosen dipandang perlu untuk terus melakukan inovasi dalam pengembangan media pembelajaran untuk perkuliahan lanjutan. Dilihat dari kesesuaian materi, 28,9\% responden menyatakan sangat sesuai, 56,0\% menyatakan sesuai, $14,8 \%$ menyatakan cukup, dan $0,3 \%$ menyatakan kurang memahami materi yang disampaikan lewat youtube. Berkaitan dengan perlunya inovasi lanjutan dalam pengembangan media pembelajaran, 86,7\% responden mendukung dilakukannya inovasi dalam pengembangan media youtube sebagai media pembelajaran pendidikan kewarganegaraan, dan $13,3 \%$ lainnya menyatakan tidak perlu dilakukan inovasi. Penelitian ini dapat memberi landasan empiris manfaat youtube yang dikembangkan dosen sebagai media pembelajaran dalam perkuliahan pendidikan kewarganegaraan di perguruan tinggi.
\end{abstract}

\section{ABSTRACT}

Changing the civic education lecture process from face-to-face to distance learning through networks demands the need for innovation and creativity of educators in developing learning media. Youtube is a platform that lecturers can develop to support online learning. The purpose of this study was to determine student responses to YouTube, which was developed by lecturers as a learning medium for online citizenship education. The research was conducted in a descriptive analytical manner to students participating in the civics education course at STP Ambarrukmo Yogyakarta. The results showed that the use of youtube media developed by lecturers could help students understand civics education lecture materials. However, lecturers are deemed necessary to continue to innovate in the development of learning media for advanced lectures. Judging from the suitability of the material, $28.9 \%$ of respondents stated that it was very suitable, $56.0 \%$ said it was appropriate, $14.8 \%$ said it was sufficient, and $0.3 \%$ stated that they did not understand the material presented via YouTube. Regarding the need for further innovation in the development of learning media, $86.7 \%$ of respondents supported innovation in the development of YouTube media as a media for learning civic education, and $13.3 \%$ stated that innovation was not necessary. This research can provide an empirical basis for the benefits of youtube which is developed by lecturers as a medium of learning in civic education lectures in universities.

\section{Pendahuluan}

Perkembangan teknologi yang semakin cepat dan terus menerus mengalami perubahan dinamis perlu disikapi dengan serius, terutama dalam dunia pendidikan. Kemajuan teknologi didorong dengan era globalisasi yang semakin meluas dari berbagai bidang kehidupan baik dari ekonomi, sosial, budaya, hukum, politik dan bahkan Pendidikan. 
Ricky Santoso Muharam, Danang Prasetyo. Pemanfaatan media youtube untuk mendukung e-learning pendidikan kewarganegaraan di perguruan tinggi

Internet menjadi salah satu kunci keberhasilan era globalisasi yang memberikan dampak yang sangat luar biasa. Apalagi munculnya berbagai aplikasi yang menunjang dalam tumbuh kembangnya internet dan menjadi segala kebutuhan dalam kehidupan era modern saat ini. Manfaat internet tidak lagi dapat dinafikan dalam kehidupan sehari-hari di era global ini. Globalisasi dan internet telah menjadikan dunia tanpa batas ruang dan waktu (Nani \& Mohamad, 2020; Ni'mah, 2019)

Kemajuan internet dan berbagai aplikasi pendukungnya perlu dimanfaatkan terutama bagi para pendidik dalam menyampaikan materi pembelajaran secara efektif dan efisien, serta dapat dipahami peserta didik secara berkelanjutan. Pendidikan perlu akrab dengan teknologi informasi dan komunikasi, serta terus melakukan inovasi pembelajaran (Firmadani, 2020).

Salah satu pemanfaatan teknologi dalam pembelajaran adalah penggunaan youtube sebagai platform sosial media yang banyak digunakan di Indonesia (L. Sari, 2020). Youtube bukan lagi sekadar aplikasi hiburan untuk menonton dan sharing video saja, melainkan fungsinya sudah beralih untuk dapat memberikan segala informasi yang dibutuhkan oleh masyarakat dari berbagai bidang. Menjamurnya content creator juga turut andil dalam berkembangnya platform youtube yang dapat memberikan informasi terbaru.

Perkembangan youtube dapat dimanfaatkan oleh para pendidik, baik dosen maupun guru terutama di masa pandemi COVID-19. Pembelajaran lewat youtube adalah upaya yang dapat memperbaiki suasana belajar yang baru dan lebih efektif (Kurniawan \& Wuryandani, 2017).

Perkembangan teknologi multimedia telah mendorong perubahan cara belajar peserta didik dalam mendapatkan informasi dan materi pembelajaran. Hal ini menjadi peluang peluang bagi para pendidik untuk mengembangkan pembelajaran yang lebih menarik dengan hasil maksimal (Karjani, 2020). Penggunaan media pembelajaran berbasis teknologi multimedia juga dapat mengurangi permasalahan-permasalahan yang terdapat dalam proses pembelajaran, salah satunya adalah penggunaan model pembelajaran yang kurang efektif dan tidak memberikan pembelajaran yang demokratis (Kurniawan \& Wuryandani, 2017).

Persoalan mendasar saat pandemi COVID-19 adalah perubahan sistem kehidupan bidang ekonomi, kesehatan, sosial, budaya dan pendidikan (Darwis, 2020). Pendidikan menjadi salah satu yang terdampak pada saat pandemi COVID-19 yang pada akhirnya pemerintah mengeluarkan kebijakan untuk proses perkuliahan maupun pembelajaran dilakukan secara daring. Kebijakan ini dikeluarkan melalui surat edaran yang dikeluarkan oleh Mendikbud Nomor 3 Tahun 2020 tentang Pencegahan COVID-19 pada Satuan Pendidikan dan Nomor 36926/MPK.A/HK/2020 tentang diberlakukannya pembelajaran daring baik untuk sekolah maupun perguruan tinggi (W. Sari et al., 2020). Kebijakan baru ini pada akhirnya sangat mempengaruhi kebiasaan baru dalam melakukan proses pembelajaran maupun perkuliahan yang biasanya dilakukan lewat tatap muka kemudian beralih lewat dunia maya.

Kompetensi dan literasi pendidik terhadap teknologi informasi dan komunikasi penting dimiliki pada masa pandemi Covid-19 ini. Guru maupun dosen harus mampu beradaptasi dengan model pembelajaran yang baru serta akrab dengan kemajuan teknologi informasi dan komunikasi, seperti penggunaan google classroom, youtube, zoom, goole meet, teams, skype, google dou, cisco webex.

Penelitian ini fokus mengkaji pemanfaatan youtube sebagai salah satu platform media pembelajaran jarak jauh pada mata kuliah pendidikan kewarganegaraan di STP Ambarrukmo Yogyakarta. Penjelasan materi kuliah pendidikan kewarganegaraan yang disimpan di Youtube dikembangkan oleh dosen mata kuliah wajib umum dalam mendukung pembelajaran elektronik (elearning) pendidikan kewarganegaraan.

Penelitian tentang pemanfaatan youtube sebagai media pembelajaran pernah dilakukan oleh Anggraini (2018) tentang pemanfaatan youtube sebagai media pembelajaran dalam meningkatkan kreatifitas guru Bahasa Inggris. Hasil penelitiannya menunjukkan bahwa youtube dapat merangsang kreatifitas, minat dan motivasi guru serta mampu meningkatkan kemampuan Bahasa Inggris siswa, serta kemampuan menyusun bahan ajar guru youtube (Anggraini, 2018).

Penelitian serupa pernah ditulis oleh Iqbal dan Irwanai (2019) tentang pengembangan video blog (vlog) channel youtube dengan pendekatan STEM sebagai media alternatif pembelajaran daring. 
Hasil penelitian menunjukkan bahwa video blog channel Youtube dengan pendekatan STEM layak digunakan sebagai media alternatif pembelajaran daring untuk peserta didik sekolah SMA/MA (Iqbal \& Irwandai, 2019). Penelitian lain tentang pengaruh penggunaan media video youtube dalam pembelajaran IPA terhadap motivasi belajar dan pemahaman konsep siswa menunjukkan ada dua perbedaan motivasi belajar dan pemahaman konsep yang mengikuti pembelajaran dengan menggunakan media rill, media video youtube (Iwantara et al., 2014).

Penelitian terdahulu baru mengkaji pemanfaatan youtube pada tingkat pendidikan dasar dan menengah. Oleh karena itu, pada penelitan ini akan memanfaatkan youtube sebagai media pembelajaraan pada mata kuliah Pendidikan Kewarganegaraan di Perguruan Tinggi. Sehingga diharapkan penelitian ini dapat memberikan kontribusi empiris bagi strategi pendidikan dengan memanfaatkan media digital pada perguruan tinggi, khususnya mata kuliah Pendidikan Kewarganegaraan.

\section{Metode}

Penelitian ini menggunakan pendekatan kualitatif dengan metode deskriptif analitis. Penelitian dilakukan pada mata kuliah Civic Education jenjang D3 Perhotelan dan S1 Pariwisata Sekolah Tinggi Pariwisata Ambarrukmo Yogyakarta, dilaksanakan pada semester ganjil tahun akademi 2020/2021, yaitu mulai Agustus 2020 sampai dengan Januari 2021. Pembuatan youtube dilakukan pada awal penelitian, dan penilaian terhadap materi dilakukan setiap sesi perkuliahan. Pengolahan data dilakukan pada Desember 2020, dan analisis dan penyusunan laporan dilakukan Januari 2021.

\section{Hasil dan Pembahasan}

Era pandemi COVID-19 telah mengubah pelaksanaan pembelajaran mata kuliah pendidikan kewarganegaraan di perguruan tinggi. Pembelajaran yang biasanya dilakukan secara tatap muka, dialihkan menjadi pembelajaran dalam jaringan (daring). Perubahan pelaksanaan pembelajaran didasarkan atas prinsip bahwa pembelajaran tetap harus berjalan, sekalipun ada keterbatasan karena pandemi COVID-19.

Mata kuliah pendidikan kewarganegaraan di perguruan tinggi merupakan “...pendidikan yang mencakup Pancasila, Undang-Undang Dasar Negara Republik Indonesia Tahun 1945, Negara Kesatuan Republik Indonesia dan Bhinneka Tunggal Ika untuk membentuk Mahasiswa menjadi warga negara yang memiliki rasa kebangsaan dan cinta tanah air" (Penjelasan Pasal 35 Ayat [3] huruf c Undang-Undang Republik Indonesia Nomor 12 Tahun 2012 tentang Pendidikan Tinggi, 2012). Mata kuliah ini merupakan muatan kurikulum wajib di perguruan tinggi yang dapat mengokohkan karakter/akhlak/adab warga negara (Arif, 2020).

Aturan terbaru tentang pendidikan kewarganegaraan tertuang dalam Keputusan Direktur Jenderal Pendidikan Tinggi Kementerian Pendidikan dan Kebudayaan Nomor 84/E/KPT/2020 tentang Pedoman Pelaksanaan Mata Kuliah Wajib pada Kurikulum Pendidikan Tinggi. Pendidikan kewarganegaraan diharapkan mampu memberikan pemahaman mengenai Pancasila, UUD 1945, Negara Kesatuan Republik Indonesia, dan Bhinneka Tunggal Ika serta implementasinya dalam membentuk mahasiswa menjadi warga negara yang memiliki rasa kebangsaan dan cinta tanah air.

Pemanfaatan youtube pada mata kuliah pendidikan kewarganegaraan merupakan solusi pembelajaran jarak jauh di masa pandemi COVID-19. Materi-materi yang disajikan melalui youtube dapat diakses mahasiswa kapan saja dan di mana saja. Karena itu, melalui pemanfaatan youtube ini, pembelajaran dapat tetap dilaksanakan sekalipun tidak bertatap muka secara langsung. Selain youtube, platform lain yang dapat digunakan untuk pembelajaran jarak jauh adalah whatsapp group, google suite for education, zenius, zoom dan lain sebagainya (Astini, 2020).

Pelaksanaan pembelajaran jarak jauh perlu didukung oleh kualitas kompetensi dosen dalam rangka peningkatan sumber daya manusia (SDM). Secara skematik, proses pendidikan jarak jauh yang mendukung peningkatan SDM itu digambarkan dari adanya kebutuhan peningkatan sumber daya manusia. Upaya-upaya tersebut melibatkan kerja sama pemerintahan wilayah dan penyelengara 
pendidikan, analisis terhadap kebutuhan pelaksana kerja terlatih dan terdidik, pelaksanaan proses pendidikan jarak jauh (W. Sari et al., 2020). Untuk dapat lebih jelasnya dapat lihat Gambar 1.

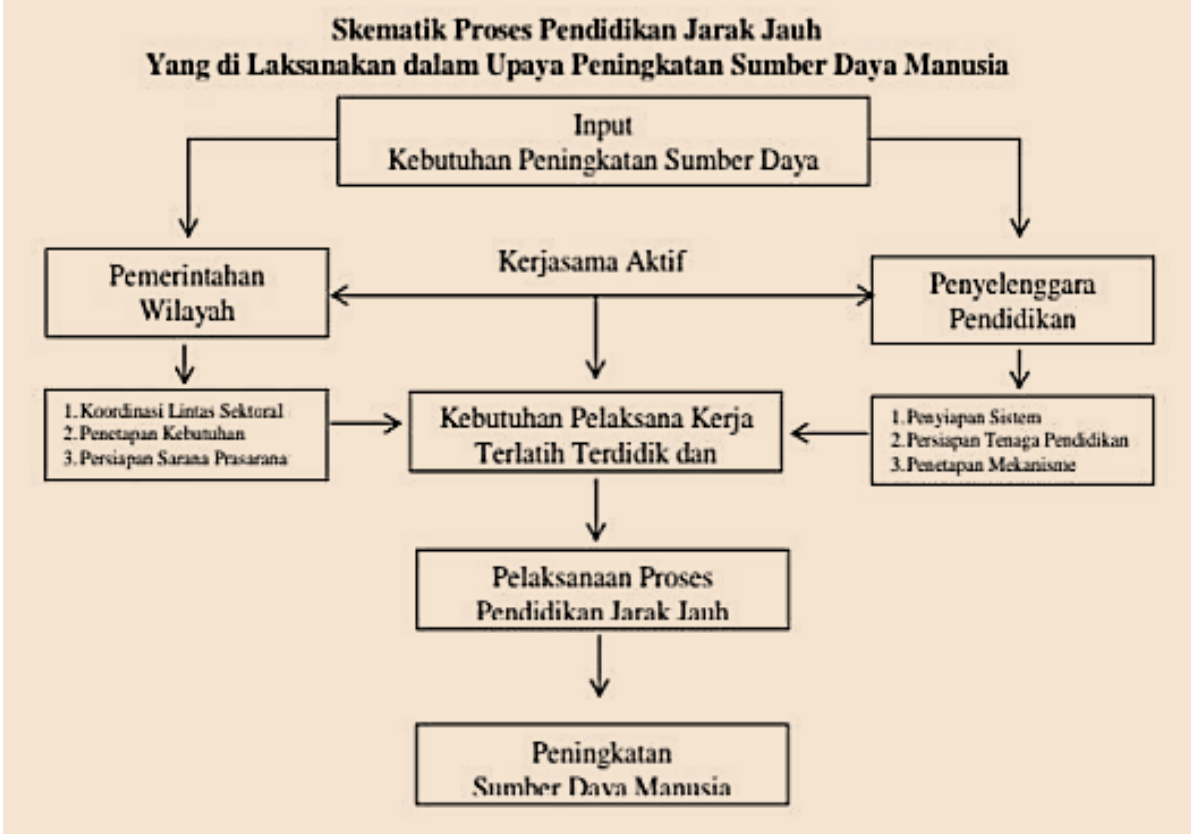

Gambar 1

Skema proses pendidikan jarak jauh yang dilaksankan dalam upaya peningkatan sumber daya manusia ( $W$. Sari et al., 2020)

Gambar 1 menunjukkan bahwa proses pendidikan jarak jauh perlu dilakukan perencanaan yang matang. Perencanaan dapat meliputi input sumber daya manusia yang dimiliki suatu lembaga, tentang kesiapan dalam pelaksanaan pembelajaran jarak jauh atau. Selain itu, perencanaan juga meliputi kesiapan pemerintah daerah dalam menyusun program-program strategis untuk mendukung terlaksananya pendidikan jarak jauh. Pemerintah daerah perlu melakukan koordinasi lintas sektoral, penetapan kebutuhan, serta menyiapkan sarana dan prasaran pendukung pembelajaran jarak jauh. Pemerintah juga dituntut memiliki kesiapan untuk menjalin kerja sama dengan penyelenggara pendidikan agar mampu melakukan penyiapan sistem, persiapan tenaga pendidik serta menetapkan model pembelajaran jarak jauh yang dapat diimplementasikan oleh pendidik, baik guru maupun dosen.

Kerja sama pemerintah dengan penyelenggara pendidikan termasuk di dalamnya untuk meningkatkan kompetensi tenaga pengajar melalui bimbingan teknis dan pelatihan. Hal tersebut agar para pendidik siap melaksanakan pendidikan jarak jauh.

\section{Pemahaman Materi}

Pembelajaran jarak jauh menuntut tersedianya akses jaringan internet yang cukup untuk pelaksanaan pembelajaran, baik secara synchronous maupun asynchronous (Didin et al., 2020). Namun, ditemukan kendala dalam pelaksanaan perkuliahan jarak jauh, antara lain kendala jaringan dan akses internet mahasiswa yang menyebabkan tidak semua mahasiswa dapat mengikuti perkuliahan jarak jauh.

Dalam upaya membantu pemahaman materi pembelajaran, dosen memanfaatkan dan mengembangkan Youtube yang berisi penjelasan materi pembelajaran sebagai media tambahan dalam perkuliahan pendidikan kewarganegaraan. Media ini disusun agar para mahasiswa mampu memahami materi yang disampaikan dosen dengan baik.

Pemanfaatan youtube sebagai model pembelajaran tentunya diharapkan dapat mempermudah para mahasiswa untuk dapat mengulang materi yang sudah dibagikan oleh dosen pengajar 
(Supriyanto, 2020). Dari Sembilan bab materi pendidikan kewarganegaraan selama satu semester, mahasiswa diminta untuk memberikan respons terhadap media youtube yang dikembangkan dosen tentang kesesuaian materi dan kemampuan pemahaman materi tersebut.

Pemahaman materi hakikat Pendidikan Kewarganegaraan, dari 120 responden, 25,2\% menyatakan sangat sesuai, $60 \%$ menyatakan sesuai dan $14,3 \%$ menyatakan cukup sesuai. Untuk dapat jelasnya lihat Gambar 2.

\section{Hakikat Pendidikan Kewarganegaraan}

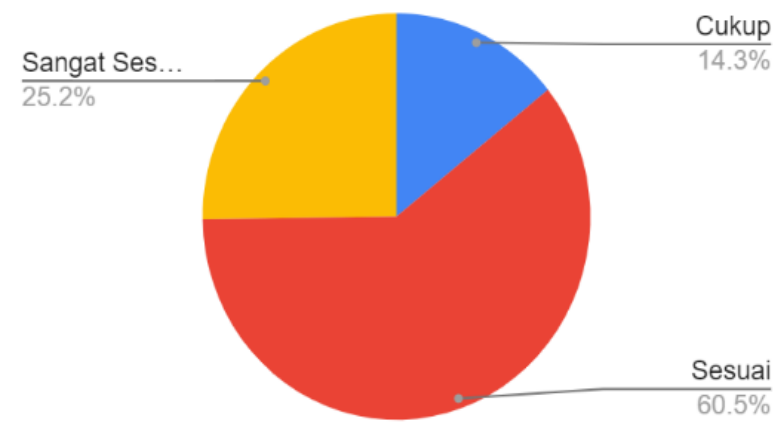

\section{Gambar 2}

Pemahaman Materi Hakikat Pendidikan Kewarganegaraan

Pemahaman materi Identitas Nasional, dari 120 responden , 25,0\% menyatakan sangat sesuai, $61,7 \%$ menyatakan sesuai, dan $13,3 \%$ menyatakan cukup sesuai. Untuk dapat jelasnya lihat Gambar 3.

\section{Identitas Nasional}

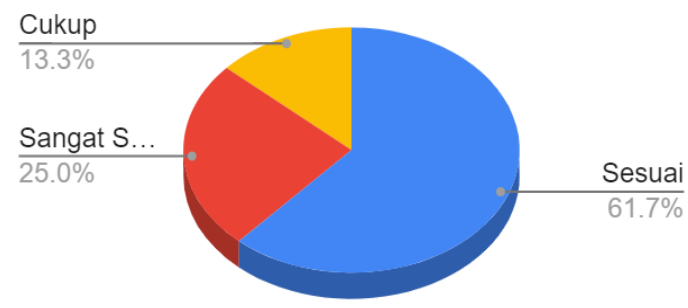

Gambar 3

Pemahaman Materi Identitas Nasional

Pemahaman materi Integritas Nasional dari 120 responden memberikan penilaian bahwa $27,5 \%$ sangat sesuai, $50,8 \%$ sesuai dan $21,7 \%$ cukup. Untuk dapat jelasnya lihat Gambar 4

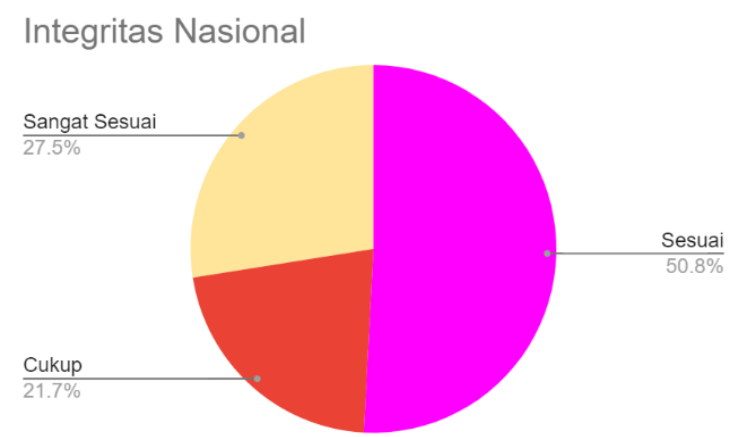

Gambar 4

Pemahaman Materi Integritas Nasional 
Ricky Santoso Muharam, Danang Prasetyo. Pemanfaatan media youtube untuk mendukung e-learning pendidikan kewarganegaraan di perguruan tinggi

Pemahaman materi Konstitusi Indonesia UUD 1945, dari 120 responden 25,2\% menyatakan sangat sesuai, 54,6\% menyatakan sesuai, $21,7 \%$ menyatakan cukup, dan $0,8 \%$ menyatakan kurang. Untuk dapat jelasnya lihat Gambar 5.

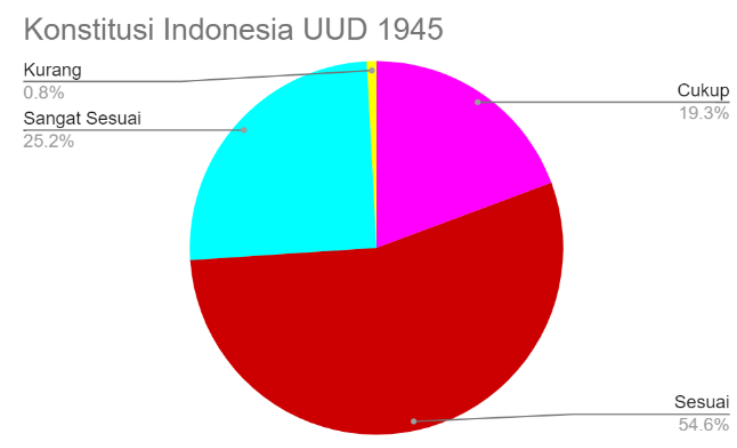

Gambar 5

Pemahaman Materi konstitusi Indonesia UUD 1945

Pemahaman materi Kewajiban dan Hak Warga Negara, dari 120 responden, 36,1\% menyatakan sangat sesuai, 48,7\% menyatakan sesuai, dan 15,1\% menyatakan cukup. Untuk dapat jelasnya lihat Gambar 6.

\section{Kewajiban dan Hak Warga Negara}

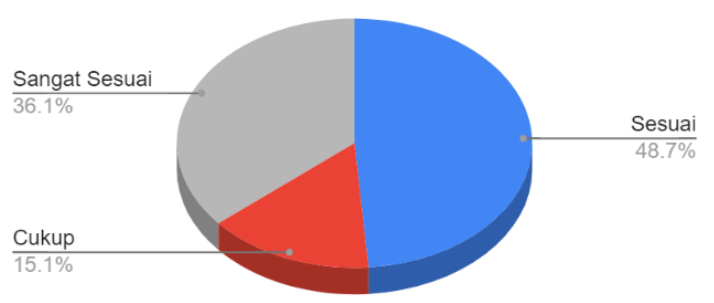

Gambar 6

Pemahaman Materi Kewajiban dan Hak Warga Negara

Pemahaman materi Demokrasi Pancasila, dari 120 responden, 25,0\% menyatakan sangat sesuai, 58,3\% menyatakan sesuai, dan 16,7\% menyatakan cukup sesuai. Untuk dapat jelasnya lihat Gambar 7.

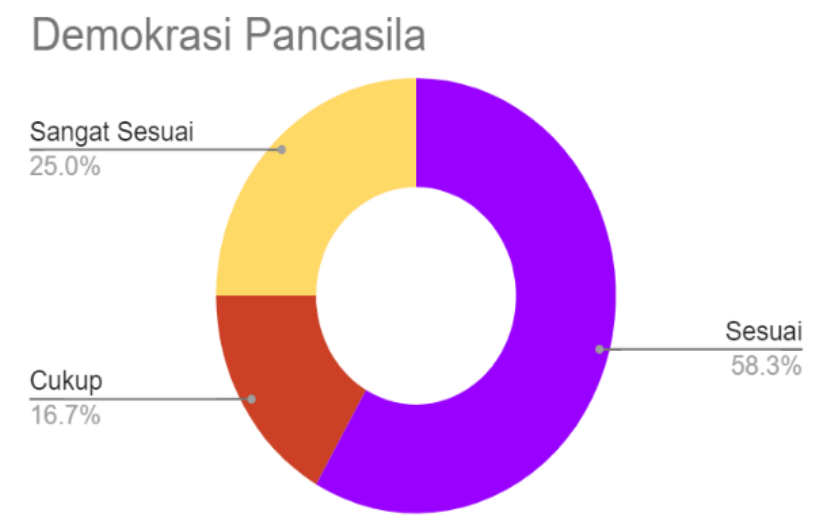

Gambar 7

Pemahaman Materi Demokrasi Pancasila 
Pemahaman materi Pemilihan Umum dan Pendidikan Politik, dari 120 responden, 26,3\% menyatakan sangat sesuai, 50,8\% menyatakan sesuai, 22,\% menyatakan cukup sesuai, dan $0,9 \%$ menyatakan kurang. Untuk dapat jelasnya lihat Gambar 8.

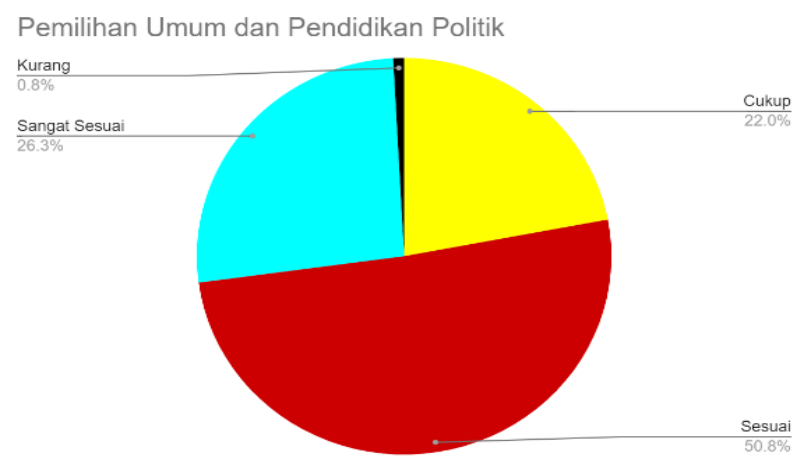

Gambar 8

Pemahaman Materi Demokrasi Pancasila

Pemahaman materi Penegakan Hukum yang Berkeadilan, dari 120 responden, 30,5\% menyatakan sangat sesuai, $52,5 \%$ menyatakan sesuai, $16,1 \%$ menyatakan cukup sesuai, dan $0,8 \%$ menyatakan kurang sesuai. Untuk dapat jelasnya lihat Gambar 9.

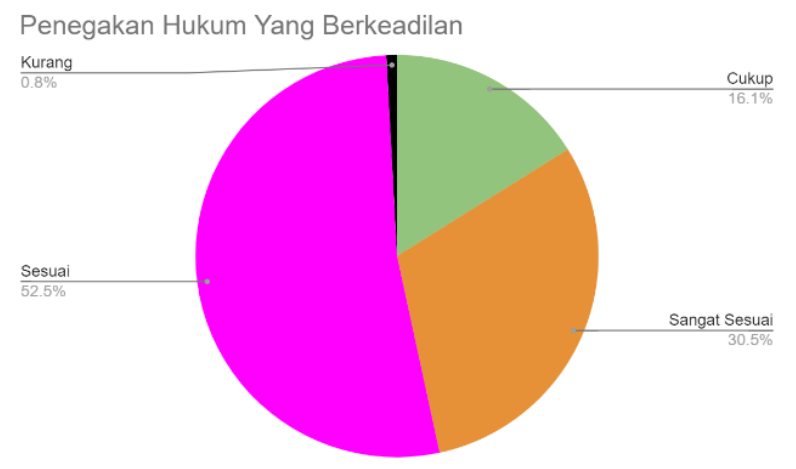

\section{Gambar 9}

Pemahaman Penegakan Hukum yang Berkeadilan

Pemahaman materi Pendidikan Anti Korupsi, dari 120 responden, 21,2\% menyatakan sangat sesuai, $63,6 \%$ menyatakan sesuai, dan 21,2\% menyatakan cukup sesuai. Untuk dapat jelasnya lihat Gambar 10.

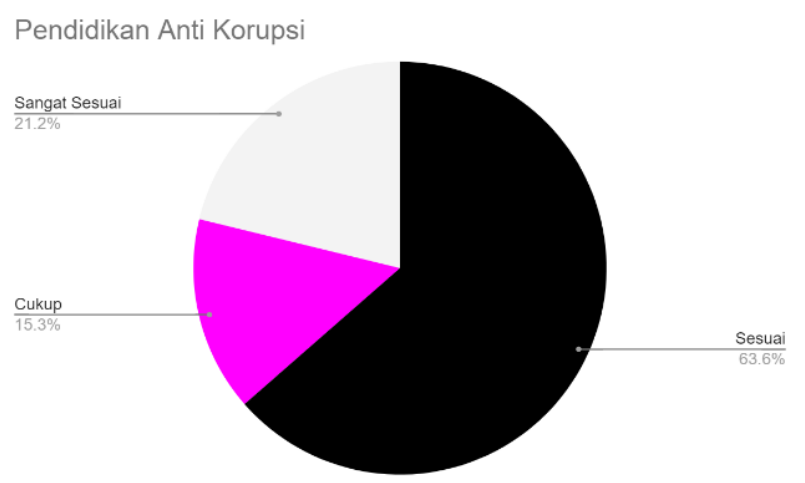

\section{Gambar 10}

Pemahaman Pendidikan Anti Korupsi 
Pemahaman materi Wawasan Nusantara, dari 120 responden, 31,1\% menyatakan sangat sesuai, 53,3\% menyatakan sesuai, dan 15,6\% menyatakan cukup sesuai. Untuk dapat jelasnya lihat Gambar 11.

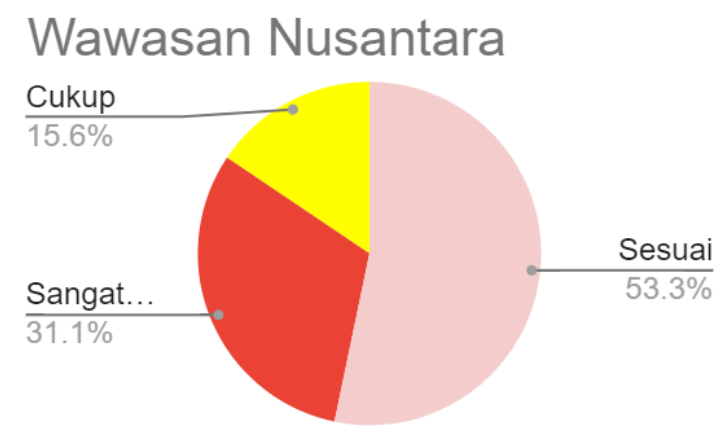

\section{Gambar 11}

Pemahaman Wawasan Nusantara

Pemahaman materi Implementasi Wawasan Nusantara, dari 120 responden, 25,2\% menyatakan sangat sesuai, 55,3\% menyatakan sesuai, 18,7\% menyatakan cukup sesuai, dan 0,8\% menyatakan kurang sesuai. Untuk dapat jelasnya lihat Gambar 12.

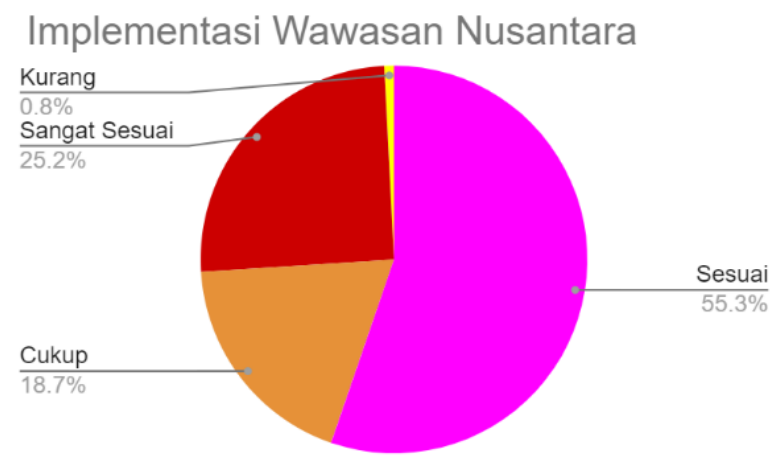

\section{Gambar 12}

Pemahaman Implementasi Wawasan Nusantara

Pemahaman materi Ketahanan Nasional, dari 120 responden, 29,0\% menyatakan sangat sesuai, $56,5 \%$ menyatakan sesuai, $13,7 \%$ menyatakan cukup sesuai, dan $0,8 \%$ menyatakan kurang sesuai. Untuk dapat jelasnya lihat Gambar 13.

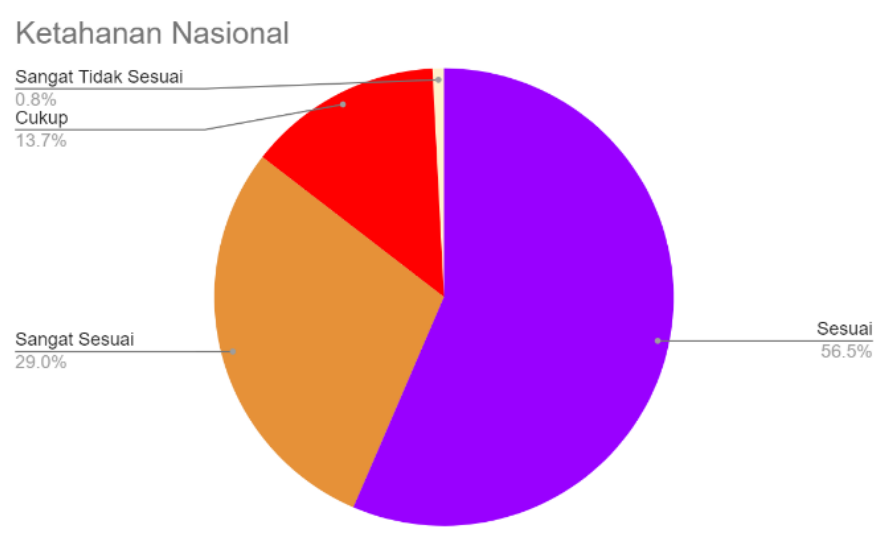

\section{Gambar 13}

Pemahaman Ketahanan Nasional 
Pemahaman materi Bela Negara, dari 120 responden, 38,7\% menyatakan sangat sesuai, 49,2\% menyatakan sesuai, $12,1 \%$, menyatakan cukup sesuai, dan $0,8 \%$ menyatakan kurang sesuai. Untuk dapat jelasnya lihat Gambar 14.

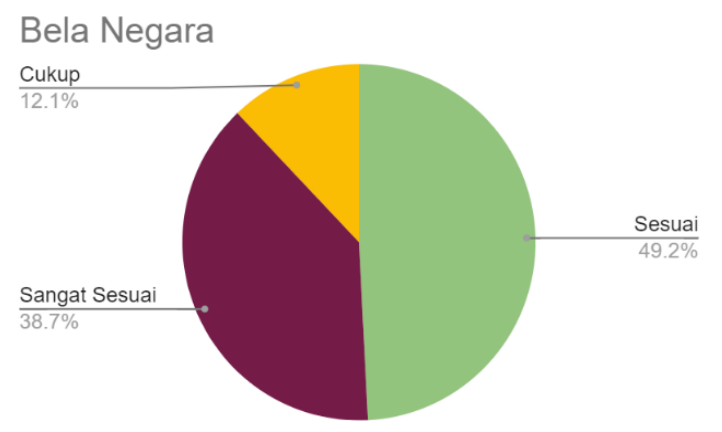

Gambar 14

Pemahaman Bela Negara

Responden yang memberikan tanggapan atas pertanyaan yang disampaikan, hasilnya sangat beragam. Namun, dari persentase angka antara yang satu dengan yang lainnya tidak jauh berbeda. Selain itu, ketika responden ditanyakan tentang perlunya inovasi lanjutan penggunaan youtube dalam proses perkuliahan, 86,7\% responden menjawab "Ya". Sedangkan 13,3\% responden lainnya menjawab "Tidak Perlu" untuk inovasi lanjutan. Artinya, para mahasiswa membutuhkan butuh media pembelajaran yang menarik dan memberi kemudahan mereka dalam memahami materi. Dalam hal ini, dosen perlu terus melakukan inovasi dalam pengembangan Youtube pembelajaran pendidikan kewarganegaraan. meningkatkan kualitas gambar, pencahayaan, background atau yang lainnya adalah inovasi yang dapat dilakukan. Untuk dapat lebih jelasnya lagi dapat dilihat pada diagram Gambar 15.

\section{Perlukan Inovasi Lanjutan Dalam Pengunaan Youtube? \\ 120 responses}

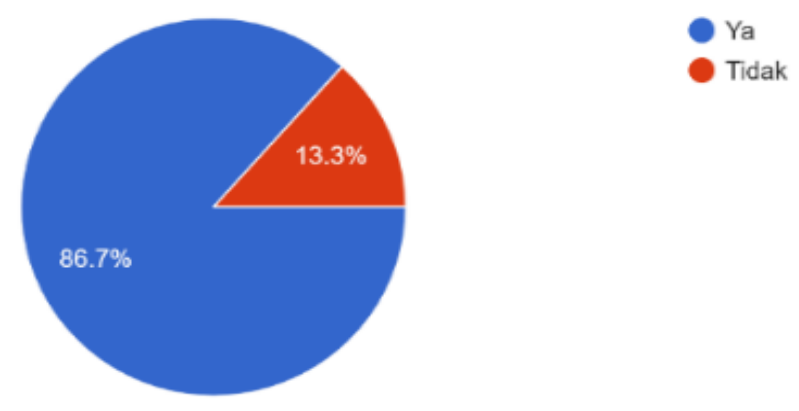

Gambar 15

Tanggapan Response tentang Inovasi Lanjutan Penggunaan Youtube

\section{Kendala Pembelajaran E-Learning}

Pembelajaran e-learning sebagai media yang cukup efektif dalam melakukan proses perkuliahan maupun pengajaran. Dengan dukungan teknologi serta internet tentunya akses untuk mendapatkan informasi sangat mudah dan dapat diselesaikan.

Proses perkuliahan yang biasanya dilakukan tatap muka dan beralih dengan menggunakan media e-learning menjadi suatu hal yang baru dan tentunya memang perlu dukungan dari semua lapisan masyarakat, pemerintah, penentu kebijakan. 
Ricky Santoso Muharam, Danang Prasetyo. Pemanfaatan media youtube untuk mendukung e-learning pendidikan kewarganegaraan di perguruan tinggi

Berbagai kendala dalam proses perkuliahan dan pembelajaran memang tentu menjadi hal yang paling utama adalah akses internet yang masih belum merata yang berada di beberapa mahasiswa. Selain itu tentunya kuota internet yang dibutuhkan untuk dapat terus digunakan untuk pembelajaran tidak semua mahasiswa secara terus-menerus dapat membeli paket kouta internet yang harganya dapat dibilang cukup mahal. Dan tak hanya itu tidak semua mahasiswa mendapatkan subsidi dari pemerintah untuk mendapatkan kuota belajar karena terbentur regulasi ataupun belum masuknya data mahasiswa dalam sistem. Dan masalah selanjutnya yakni adanya kejenuhan yang dihadapi oleh mahasiswa yang harus secara terus menerus mengikuti perkuliahan daring sehingga pembelajaran menjadi terhambat karena kurangnya konsentrasi dalam mengikuti perkuliahan.

Dari berbagai persoalan yang ada perlu ada suatu kebijakan maupun terobosan untuk mengatasi masalah-masalah dalam proses perkuliahan maupun pembelajaran e-learning.

\section{Simpulan}

Pemanfatan media youtube dalam media mendukung e-learning memang disikapi beragam. Media youtube yang digunakan untuk sarana pendukung e-learning sebetulnya dapat membantu mahasiswa dalam memahami materi perkuliahan. Mengingat sistem perkuliahan tanpa tatap muka tentu saja sangat menyulitkan mahasiswa. Dengan adanya media youtube untuk mempermudah mahasiswa dalam mengkaji ulang materi perkuliahan dapat dilakukan dengan secara berulang-ulang dengan menonton youtube yang sudah dibuat dan dirancang oleh dosen.

Dari 14 (empat belas) kali pertemuan yang asumsinya setiap pertemuan akan didukung dengan memanfaatkan media youtube berupa video dimana dosen menjelaskan materi powerpoint serta video supaya para mahasiswa mampu mengulang materi yang terlewat saat pembelajaran secara daring dengan menggunakan google classroom, youtube, zoom, goole meet, teams, skype, google dou, cisco webex.

Pemahaman mahasiswa dari 14 (empat belas) materi yang ditampilkan merespon terkait pemahaman mahasiswa dalam menyimak isi materi dengan menonton youtube. Untuk dapat memahami lebih jelas dapat dilihat pada Tabel 1.

Tabel 1

Penilaian Mahasiswa terhadap Kesesuaian Penjelasan melalui Youtube

\begin{tabular}{|c|c|c|c|c|}
\hline \multirow{2}{*}{ Materi } & \multicolumn{4}{|c|}{ Pemahaman materi } \\
\cline { 2 - 5 } & Sangat Sesuai & Sesuai & Cukup & Kurang \\
\hline Hakikat pendidikan kewarganegaraan & 30 & 75 & 18 & 0 \\
\hline Identitas Nasional & 30 & 78 & 18 & 0 \\
\hline Integritas nasional & 33 & 64 & 18 & 0 \\
\hline Konstitusi Indonesia UUD 1945 & 30 & 69 & 18 & 1 \\
\hline Kewajiban dan Hak Warga Negara & 43 & 61 & 18 & 0 \\
\hline Demokrasi Pancasila & 30 & 74 & 18 & 0 \\
\hline Pemilihan Umum dan Pendidikan & 31 & 63 & 18 & 0 \\
\hline Penegakan Hukum Yang Berkeadilan & 36 & 66 & 18 & 1 \\
\hline Pendidikan anti korupsi & 30 & 77 & 18 & 0 \\
\hline Wawasan Nusantara & 38 & 65 & 18 & 0 \\
\hline Ketahanan Nasional & 36 & 70 & 18 & 1 \\
\hline Bela Negara & 48 & 61 & 18 & 0 \\
\hline
\end{tabular}

Tabel 1 menunjukkan bahwa pemahaman materi secara keseluruhan mahasiswa menjawab $28,9 \%$ sangat sesuai, $56,0 \%$ sesuai, $14,8 \%$ cukup, $0,3 \%$ kurang memahami materi yang disampaikan lewat youtube. Untuk dapat dipahami lebih jelas dapat melihat pada Gambar 16.

Hasil penelitian ini menyimpulkan bahwa sebagian besar mahasiswa mampu menyerap materi yang disampaikan oleh dosen dengan menggunakan menyerap materi yang disampaikan oleh dosen dengan menggunakan youtube sebagai sarana perkuliahan yang cukup efektif. 


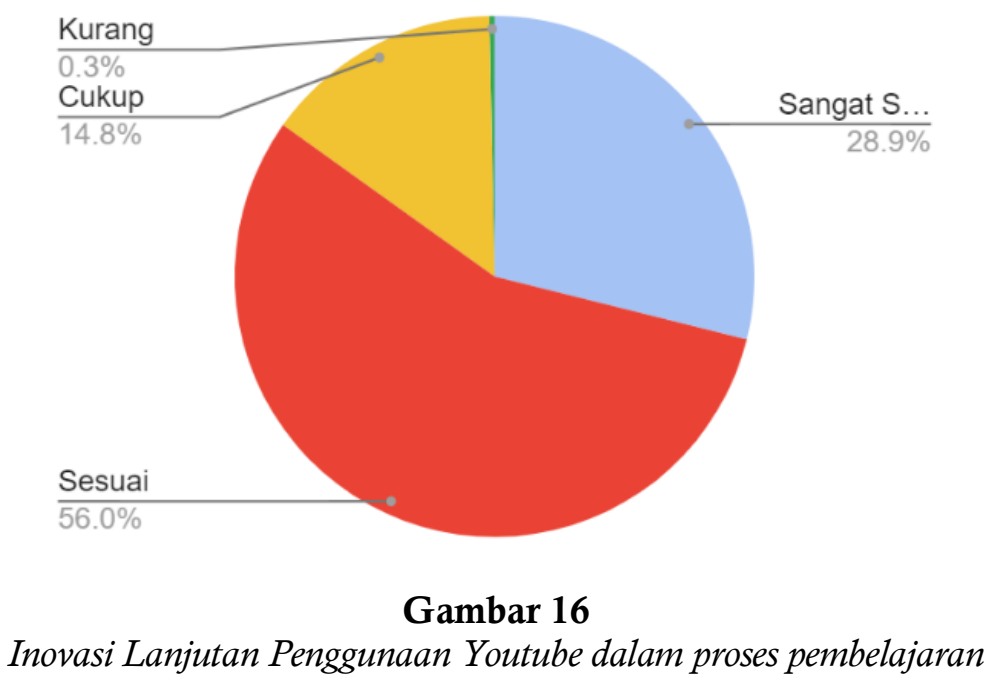

\section{Ucapan Terima Kasih}

Ucapan terima kasih kepada Sekolah Tinggi Pariwisata Ambararrukmo yang turut membantu jalannya penelitian ini. Termasuk kepada jajaran tim dosen Mata Kuliah Wajib Umum Pendidikan Pancasila dan Kewarganegaraan, Sekolah Tinggi Pariwisata Ambarrukmo yang turut serta mendukung penelitian ini sehingga dapat berjalan dengan baik lancar.

\section{Referensi}

Anggraini, D. R. (2018). Pemanfaatan Youtube Sebagai Media Pembelajaran Dalam Meningkatkan Kreatifitas Guru Bahasa Inggris Mts Al-Insan. Universitas Muhammadiyah Tanggerang, 446-452.

Arif, D. B. (2020). Reorientasi Pendidikan Kebangsaan Berbasis Adab: Konsep dan Problematiknya. PKn Progresif: Jurnal Pemikiran dan Penelitian Kewarganegaraan, 15(1), 14-38.

Astini, N. K. S. (2020). Pemanfaatan Teknologi Informasi dalam Pembelajaran Tingkat Sekolah Dasar pada Masa Pandemi Covid-19. Jurnal Lembaga Penjaminan Mutu STKIP Agama Hindu Amlapura, 11(2), 13-25.

Darwis, P. (2020). COVID-19 Mengubah Kehidupan Kita. Jurnal llmu Bedah Indonesia, 48(1), 1-2.

Didin, F. S., Mardiono, I., \& Yanuarso, H. D. (2020). Analisis Beban Kerja Mental Mahasiswa saat Perkuliahan Online Synchronous dan Asynchronous Menggunakan Metode Rating Scale Mental Effort. OPSI, 13(1), 49-55.

Firmadani, F. (2020). Media Pembelajaran Berbasis Teknologi Sebagai Inovasi Pembelajaran Era Revolusi Industri 4.0. KoPeN: Konferensi Pendidikan Nasional, 2(1), 93-97.

Iqbal, M., \& Irwandai, S. L. (2019). Pengembangan Video Blog (Vlog) Channel Youtube Dengan Pendekatan Stem Sebagai Media Alternatif Pembelajaran Daring. Inovasi Pembangunan: Jurnal Kelitbangan, 7(2), 135-148. https://doi.org/10.35450/jip.v7i2.140

Iwantara, I. W., Sadia, I. W., \& Suma, I. K. (2014). Pengaruh Penggunaan Media Video Youtube Dalam Pembelajaran IPA Terhadap Motivasi Belajar Dan Pemahaman Konsep Siswa. e-journal Program Pascasarjana Universitas Pendidikan Ganesha, 4.

Karjani. (2020). Peningkatan kompetensi guru dalam pembelajaran berbasis multimedia interaktif melalui in house training di SD Negeri Giriwoyo. Elementary School, 7(1), 108-116.

Kurniawan, M. W., \& Wuryandani, W. (2017). Pengaruh model pembelajaran berbasis masalah terhadap motivasi belajar dan hasil belajar PPKn. Jurnal Civics: Media Kajian Kewarganegaraan, 14(1), 10-22. https://doi.org/10.21831/civics.v14i1.14558

Nani, U., \& Mohamad, K. (2020). Kajian riset mengenai pendidikan Islam yang berorientasi pada isu-isu sosial sebagai dampak globalisasi. Jurnal Al-Amar (Ekonomi Syariah, Perbankan Syariah, 
Ricky Santoso Muharam, Danang Prasetyo. Pemanfaatan media youtube untuk mendukung e-learning pendidikan kewarganegaraan di perguruan tinggi

Agama Islam, Manajemen dan Pendidikan), 1(4), 51-61.

Ni'mah, U. (2019). Pemanfaatan Internet Sebagai Sumber Belajar Pendidikan Agama Islam. Conference on Islamic Studies FAI 2019, 326-340.

Sari, L. (2020). Upaya Menaikkan Kualitas Pendidikan dengan Pemanfaatan Youtube Sebagai Media Ajar Pada Masa Pandemi COVID-19. Jurnal Tawadhu, 4(1), 1074-1084.

Sari, W., Rifki, A. M., \& Karmila, M. (2020). Pembelajaran Jarak Jauh Pada Masa Darurat Covid 19. Jurnal MAPPESONA, 1, 12.

Supriyanto, E. E. (2020). Pengembangan Media Pembelajaran Mata Kuliah Pendidikan Kewarganegaraan Dimasa Pandemi Menggunakan Portal Elearning dan Youtube Chanel (Studi Kasus di STKIP NU Kabupaten Tegal). UrbanGreen Conference Proceeding Library, 1, 138-142.

Undang-Undang Republik Indonesia Nomor 12 Tahun 2012 tentang Pendidikan Tinggi, (2012). 